\title{
ANXIETY AND CONCENTRATION OF TENNIS CHAIR UMPIRE
}

\author{
Septian Raibowo', Rices Jatra², Andika Prabowo ${ }^{3}$, Yahya Eko Nopiyanto ${ }^{4}$, \\ Bogy Restu Ilahi ${ }^{5}$ \\ Universitas Bengkulu ${ }^{1,3,4,5}$, Universitas Islam Riau ${ }^{2}$ \\ septianraibowo@unib.ac.id,ricesjatra@edu.uir.ac.id, andikaprabowo@unib.ac.id, \\ yahyaekonopiyanto@unib.ac.id,bogyrestu@unib.ac.id
}

\begin{abstract}
The purpose of this research to understand the correlation between anxiety and concentrate on the tennis chair umpire. The subject of this research is tennis chair umpire on Asian School Games 2019 were 30. The measurement of variable anxiety scales anxiety of sports and variable concentration uses a grid exercise concentration. An analysis of the data used was product moment correlation. The data analysis used is product moment correlation. The data analysis showed a correlation coefficient of 0.782 and belonged to the strong category and contributed correlation between variables of 0.612 or $61.2 \%$. Of these correlation coefficient values in the strong category. That is, if the level of anxiety is high then the lower the level of concentration of the referee and vice versa, the increase in concentration will be followed by a decrease in anxiety
\end{abstract}

Keywords: Anxiety; Asian School Games; Concentration; Tennis Chair Umpire

Accepted: 9th of July 2021

Correspondence author: Septian Raibowo, Universitas Bengkulu, Indonesia. E-Mail: septianraibowo@unib.ac.id

DOI http://dx.doi.org/10.31851/hon.v4i25640

\section{(i) (2)}

Jurnal Halaman Olahraga Nusantara licensed under a Creative Commons Attribution-ShareAlike 4.0 International License.

\section{INTRODUCTION}

Sports is one form of efforts to improve the quality of Indonesian people shown in the formation of high traits, character, discipline, and sportsmanship, as well as improved achievements that can evoke a sense of national pride. Sports is also an inseparable part of the nation's development in order to improve the quality of human resources (Raibowo et al., 2021). Sports activities include various sports such as athletics (Ilahi et al., 2020), games, water sports, as well as martial arts sports. Sports games that are increasingly favored by the public is the sport of tennis courts. In Asia, tennis courts rank fifth in a row under football, badminton, swimming and basketball (Hakuhodo Inc., 2012). ). Later in the United States, tennis courts were included in the top five sports that are often 
performed with basketball in the first place (NPR et al., 2015). Of course this is enough to describe the existence of tennis court much loved by the public in the world, in addition to the achievements are also useful for body fitness. Tennis courts make a significant contribution to the health and fitness of one's body (Raibowo et al., 2020).

The achievements obtained by a person are a series of several stages that they do programmatically and systematically and many factors that can influence the achievement, both internal factors of the ability of the athlete himself, the training program designed (Arifianto et al., 2021), as well as the intake of nutrients and nutrients. While external factors are spectators during matches, parents, sports administrators and also the leadership of referees during matches.

The referee is a person who is appointed or assigned and has the authority to arrange the course of a match (Hadi, 2019). A competent referee can be seen in his ability to lead sports matches. In other words, a successful referee on the field is a referee who is able to make the match run safely and smoothly without any protests from players (Jatra \& Fernando, 2019). Decision making must be based on fairplay, sportsmanship, objectivity and consistency (Kodrat et al., 2020), as well as effectiveness is the most important component of a referee's performance (Bloß et al., 2020). The game of tennis is a game that is played on a rectangular court and is divided into 2 (two) parts by the net and using tools in the form of a racket and ball (Arifianto \& Raibowo, 2020). With the characteristics of these sports, the game is played with fast intensity and high tension, so it needs carefulness and accuracy in making a decision such as whether the ball falls right on the field line or outside the line. As a result, the right decision making in the middle of such an atmosphere is right to do (Larkin et al., 2011).

Seeing that, the referee must really have mental, concentration and strong motivation in leading the game. Concentration is needed for athletes in accordance with sports that specifically require the application of increasing accuracy (Arisman et al., 2021). A referee must have a low level of anxiety and 
HALAMAN Jendral A. Yani Street Lorong Gotong Royong 9/10 Ulu OLAHRAGA JURALL JUIIKEOLIRLYHA

Palembang South Sumatera

email jurnal: jurnalhon@univpgri-palembang.ac.id situs web: http://www.univpgri-palembang.ac.id

\section{Accredited}

SINTA 3

should be able to master it (Yusuf et al., 2017). However high or low anxiety depends on factors such as: skill level and experience (Tangkudung, 2018). Referees have a stressful aspect in leading the game (Agyei, 2019).

Anxiety in dealing with a match can be divided into 2 types (Tangkudung, 2018) state anxiety (state-A) and trait anxiety (trait-A). Bebetsos et al., (2013) further explained that anxiety as a state anxiety or trait anxiety has two components, namely cognitive anxiety and somatic anxiety. Furthermore, cognitive anxiety is a mental component, namely the emergence of anxiety due to a fear of negative social assessment, fear of failure and loss of self-esteem. Somatic anxiety is a physical component and reflects physiological responses, such as increased heart rate, breathing and muscle tension. Somatic anxiety refers to individual physiological arousal arrests that have negative characteristics, such as increased pulse rate, abdominal pain, sweating and others. Indicators that can be used as an anxiety can be seen from physical changes (Komaruddin, 2017).

A referee also needs a high concentration so as not to be late to make decisions, act hesitantly or wrongly make decisions that will result in a referee experiencing anxiety or fear that will later affect the decision and objectivity of the referee. Concentration is a person's ability to focus his attention and mind only on the information that is important to the success of his performance in leading the game (Jannah, 2017). When concentrating, he will sort out information that does not facilitate his performance and focus only on relevant information.

Referees have a high level of emotion and tend not to be able to control it, will result in the performance of the referee at the time of leading the match (Irawan et al., 2020). Therefore, a referee must be able to control his emotions even if the situation and conditions are under pressure from players and spectators. The pressure experienced by this referee has symptoms of stress that can have an impact on his decision (Julian, 2020) as a result of losing concentration while leading the game. The inability of a referee to concentrate is 
caused by the presence of stimulu-stimulu of thegu originating from outside and inside (Komaruddin, 2017).

The physical condition of a referee is also influential in the decision making of a referee. In addition to having the skills of competence and knowledge and communication referees must also have good physical fitness as well (Fikri, 2018). Poor physical fitness and impaired psychological condition due to anxiety felt by the referee can hinder concentration so that it will be able to impact decision making. Therefore, this study was conducted to determine whether or not there is a correlation between anxiety and concentration on the tennis chair umpire

\section{METHOD}

This research is correlational research. This research was conducted when the match event ended (questionnaires and tests). The study did not use any particular sampling technique because it is a population study. The population in this study was referees who served at the 2019 Asian School Games who had a license of 30 respondents

The spread of questionnaires and concentration tests was used as a data collection technique in this study. Research instruments on the aspect of anxiety (anxiety) using a questionnaire totaling 35 points of questions with obtained Validity 0.74 and Realibility 0.85 then concentration research instrument using Grid concentration exercise, which is a concentration test table containing numbers 00-99 arranged randomly, with respondents sorting numbers in a runtut for 1 minute (Tache et al., 2017). The more numbers that are successfully sorted, the higher the concentration (Sin \& Aprinanda, 2020)

The data analysis technique in this study used Product Moment Correlation analysis test to find the level of correlation coefficient between variables (Widiastuti et al., 2017), ), but before that a simple regression analysis and prerequisite analysis test will be conducted. To test the normality of the data using lielifors test method with comparison of Lcount and Ltabel as well as simple linear regression analysis. With equations 


$$
\begin{aligned}
& Y=a+b x \\
& Y=-10,43+0,18 x
\end{aligned}
$$

\section{RESULT AND DISCUSSION}

Based on the data analysis conducted, obtained the results of the data normality test of each variable

Table 1. Normality Test Results

\begin{tabular}{ccc}
\hline & Variabel & Sig \\
\hline & Anxiety & 0,410 \\
& Concentration & 0,214 \\
\hline$\alpha=0,05$ & &
\end{tabular}

From the data obtained sig. $>0.05$ then the data is categorized as normal. Then the correlation data between variables obtained a yield of 0.782

Table 2. Product Moment Correlation Results

\begin{tabular}{cc}
\hline$R$ & $R_{\text {Square }}$ \\
\hline 0,782 & 0,612 \\
\hline
\end{tabular}

Based on data from Table 2 above, it can be seen that the contribution of anxiety predictor variable to concentration variable is $61.2 \%$, then the correlation rate in both variables is obtained by a value of 0.782 with a strong classification.

Table 3. Product Moment Correlation Results

\begin{tabular}{cc}
\hline Correlation coefficient inteval & Category \\
\hline $0,00-0,199$ & Very Weak \\
$0,20-0,399$ & Weak \\
$0,40-0,599$ & Moderate \\
$0,60-0,799$ & Strong \\
$0,80-1,00$ & Very Strong \\
\hline
\end{tabular}

(Prabowo et al., 2020) 
Based on the analysis of the data obtained shows three things. First, the data is normally distributed with sig. $>0.05$. Second, the relationship between anxiety and concentration falls into a strong category. Third, the percentage correlation between anxiety and concentration was $61.2 \%$. That means, any increase in anxiety will be followed by a decrease in the concentration level of the referee. Similarly, any decrease in anxiety levels will be accompanied by an increase in the concentration level of the referee.

\section{DISCUSSION}

Concentration plays a very important role in performances, if it is disrupted it will cause problems, especially when the court tennis referee is on duty with a high level of accuracy in seeing the ball fall and make decisions quickly and in conditions of high match tension. Concentration is one of the psychological factors that affect performance (Triananda et al., 2021)

Concentration is the main factor that must be possessed by a referee when on duty on the field, many factors that affect the level of concentration of a referee, among others lifestyle, patterns of daily habits such as quality of sleep. Poor sleep quality has negative effects including headaches and difficulty concentrating (Djamalilleil et al., 2020; Jalali et al., 2020; Zavecz et al., 2020).

The solution that can be done by a referee to maintain concentration, should be done with a healthy lifestyle and doing exercises that can increase concentration. Concentration exercises that can be done is by training relaxation attention is a technique for reducing anxiety, stress and stress so as to maximize the use of the visual senses (Mulyana et al., 2013). In addition, by doing imagery exercises can increase concentration and reduce anxiety (Haghkhah et al., 2014). Imagery exercises can produce a better psychological response, which can stimulate the emergence of more endorphin hormones (Septiyanto \& Suharjana, 2016), thus providing a calm and comfortable effect while on duty in the field. This relaxation effect will help the referee to concentrate better. 
HALAMAN Jendral A. Yani Street Lorong Gotong Royong 9/10 Ulu OLAHRAGA

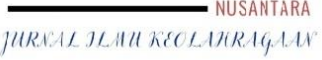

Accredited

SINTA 3

Furthermore, anxiety has its own role to the appearance of a referee on duty on the field. In general, referees who are experiencing anxiety are characterized by symptoms that are usually followed by tension or stress on the referee. Indicators that can be used as an anxiety referee can be seen from physical and psychic changes, including changes in behavior, restlessness, sleeplessness, changes in respiratory rhythm, unstable emotions and decreased confidence (Komaruddin, 2017), increased pulse, abdominal pain, sweating and so on (Bebetsos et al., 2013).

The most effective way to overcome anxiety is by relaxing exercises. Relaxation exercises are very effective given to someone who is in a tense state (Tangkudung, 2018). Relaxation exercises and psychingup can be combined with music often called pre task music (Karageorghis \& Priest, 2012). Listening to music before duty may have stimulation or positive effects (Terry \& Karageorghis, 2011). The results of research on relaxation techniques and psyching up conducted by the Brazilian Olympic Committee showed that, the technique is proven to help a person to manage anxiety and arousallevels, hence improving their performance (Pineschi \& di Pietro, 2013). Apart from doing relaxation exercises and listening to music, managing anxiety can be done by exercising regularly. Doing regular exercise can increase endurance and reduce the level of stress events caused by feelings of anxiety and can manage the mood experienced (Asri \& Setiandari, 2021)

Then in addition to doing relaxation exercises, to manage anxiety is to do self talk techniques. Sometimes a referee who wants to be in charge of the game is hesitant and anxious about success in leading the game, this hesitation must be addressed immediately by telling himself that he is capable. A successful self-talk exercise is when one is able to get rid of doubtful and fearful thoughts and replace them with optimistic speech and sentences (Tangkudung, 2018).

Based on this, it is clear that anxiety and concentration is an important thing that must be managed and maintained by a referee. A referee must have a high 
level of concentration so as not to be late to make decisions, act hesitantly or wrongly take decisions that will result in a referee experiencing anxiety or fear that will later affect the decision and objectivity of the referee

\section{CONCLUSION}

Based on the analysis of data, it can be concluded that the concentration level of court tennis referees has a significant relationship with the level of anxiety. The correlation coefficient value obtained was 0.782 and falls into the strong category and contributes to the correlation between variables of 0.612 or $61.2 \%$. From the value of the correlation coefficient can be interpreted if the level of anxiety is high then the lower the level of concentration of the referee and vice versa, the increase in concentration will be followed by anxiety lowering.

\section{REFERENCES}

Agyei, M. (2019). Home-Advantage Decision-Making: Experiences Of Soccer Referees At The 23rd GUSA Games. International Journal of Advanced Research and Publication, 3(6), 97-107.

Arifianto, I., \& Raibowo, S. (2020). Model Latihan Koordinasi dalam Bentuk Video Menggunakan Variasi Tekanan Bola Untuk Atlet Tenis Lapangan Tingkat Yunior. STAND: Journal Sport Teaching and Development, 1, 4955. https://doi.org//10.36456/j-stand.v1i2.2671

Arifianto, I., Raibowo, S., \& Jatra, R. (2021). Groundstroke Training Games Dalam Bentuk Video untuk Atlet Junior Tenis Lapangan. Jurnal Menssana, 6(1), 12-22. https://doi.org/10.24036/MensSana.06012021.18

Arisman, A., Okilanda, A., Dwiansyah Putra, D., \& El Cintami Lanos, M. (2021). Jurnal Patriot. Resistensi Yoga Dalam Meningkatkan Konsentrasi Ketepatan Memanah, 3, 71-81. https://doi.org/10.24036/patriot.v

Asri, N., \& Setiandari, E. L. O. (2021). Sport Activities During The Covid-19 Pandemic Against The Stress Level of Students of Sports Education of The Islamic University of Kalimantan Muhammad Arysad Al Banjari Banjarmasin. Jurnal Halaman Olahraga Nusantara (HON), 4(1), 53-65. https://doi.org/10.31851/hon.v4i1.5213

Bebetsos, E., Zouboulias, S., Antoniou, P., \& Kourtesis, T. (2013). Do anxiety, anger and aggression differentiate elite water-polo players? Journal of 
HALAMAN Jendral A. Yani Street Lorong Gotong Royong 9/10 Ulu OLAHRAGA

Physical Education and Sport, 13(2), 209-212.

https://doi.org/10.7752/jpes.2013.02035

Bloß, N., Schorer, J., Loffing, F., \& Büsch, D. (2020). Physical load and referees' decision-making in sports games: A scoping review. Journal of Sports Science and Medicine, 19(1), 149-157.

Djamalilleil, S. F., Rosmaini, R., \& Dewi, N. P. (2020). Hubungan Kualitas Tidur Terhadap Konsentrasi Belajar Mahasiswa Fakultas Kedokteran Universitas Baiturahmah Padang Angkatan 2018. Journal Health and Medical Journal, 3(1), 43-50. https://doi.org/10.33854/heme.v3i1.339

Fikri, A. (2018). Tinjauan Kondisi Fisik Wasit Sepak Bola Pengcab PSSI Kota Lubuklinggau. Gelanggang Olahraga: Jurnal Pendidikan Jasmani Dan Olahraga (JPJO), 2(1), 140-149. https://doi.org/10.31539/jpjo.v2i1.420

Hadi, H. (2019). Pemahaman Peraturan Permainan Tenis Pada Peserta Penataran Wasit Tenis Di Universitas Pgri Semarang. Multilateral Jurnal Pendidikan Jasmani Dan Olahraga, 17(2), 98-102. https://doi.org/10.20527/multilateral.v17i2.5707

Haghkhah, A., Sohrabi, M., Hamidreza, T. T., Ghalehroudhkani, H. H., \& Tabar, M. G. (2014). The Effect of Mental Imagery Focus of Attention on Performance and Learning of Children Dart Throwing Skill. International Journal of Sport Studies, 4(1), 161-167.

Hakuhodo Inc. (2012). Sports Popular in 14 Asian Countries. Global Habit, 3(1), $1-10$.

Ilahi, B. R., Syafrial, \& Hiasa, F. (2020). Implementasi Model Pembelajaran Kooperatif Tipe Numbered Heads Together pada Mahasiswa Pendidikan Jasmani Universitas Bengkulu. Halaman Olahraga Nusantara (Jurnal Ilmu Keolahragaan), 3(2), 207-213. https://doi.org/10.31851/hon.v3i2.4858

Irawan, D. K., Ramadhan, C. U., Bakhri, R. S., \& Latif, M. (2020). Kinerja Wasit Bola Voli Indoor Ditinjau Dari Perbedaan Gender. Biormatika: Jurnal Ilmiah Fakultas Keguruan Dan Ilmu Pendidikan, 6(02), 55-60. https://doi.org/10.35569/biormatika.v6i02.815

Jalali, R., Khazaei, H., Khaledi Paveh, B., Hayrani, Z., \& Menati, L. (2020). The Effect of Sleep Quality on Students' Academic Achievement. Journal Advances in Medical Education and Practice, 11, 497-502. https://doi.org/10.2147/AMEP.S261525

Jannah, M. (2017). Kecemasan dan Konsentrasi Pada Atlet Panahan. Jurnal Psikologi Teori Dan Terapan, 8(1), 53-60.

Jatra, R., \& Fernando, D. D. (2019). Pemahaman Peraturan Permainan Tenis Lapangan Pada Peserta Penataran Wasit Tenis Lisensi Daerah. Sportif: 


\section{OLATRAGA}

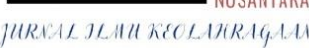

Jendral A. Yani Street Lorong Gotong Royong 9/10 Ulu Palembang South Sumatera

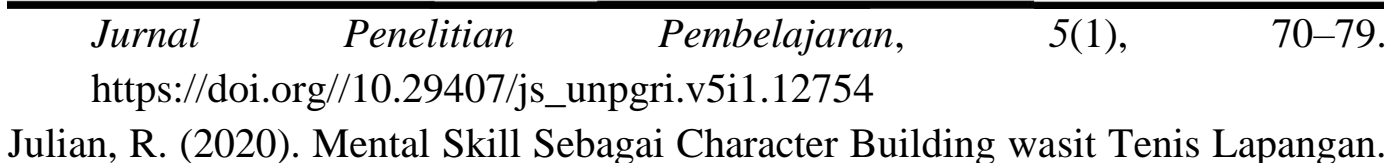
Journal of Sport and Health, 2(1), 15-19. https://doi.org/10.26486/jsh.v2i1.1515

Karageorghis, C. I., \& Priest, D. L. (2012). Music in the exercise domain: a review and synthesis (Part II). Journal International Review of Sport and Exercise Psychology, 5(1), 67-84. https://doi.org/10.1080/1750984X.2011.631027

Kodrat, H., Kusmaedi, N., \& Hamidi, A. (2020). Tingkat Kepuasan Wasit Sepakbola dalam Mengambil Keputusan Berdasarkan Tingkat Pendidikan. Medikora, 19(1), 40-45. https://doi.org/10.21831/medikora.v19i1.30514

Komaruddin. (2017). Psikologi Olahraga Latihan Keterampilan Mental dalam Olahraga Kompetitif(V). Remaja Rosdakarya.

Larkin, P., Berry, H., \& Dawson, B. (2011). Assesment of Umpire Perceptual and Decision-making Skill in Austarlian Football. Journal of Science and Medicine in Sport, 14(2011), e86-e87. https://doi.org/10.1016/j.jsams.2011.11.178

Mulyana, O. P., Izzati, U. A., \& Puspitadewi, N. W. S. (2013). Penerapan Relaksasi Atensi Untuk Meningkatkan Konsentrasi Belajar Pada Siswa SMK. Jurnal Psikologi Teori Dan Terapan, 3(2), 103. https://doi.org/10.26740/jptt.v3n2.p103-112

NPR, Robert Wood Johnson Foundation, \& Harvard T.H. Chan School of Public Health. (2015). Sports and Health in America. June, 73.

Pineschi, G., \& di Pietro, A. (2013). Anxiety Management Through Psychophysiological Techniques: Relaxation and Psyching-up in Sport. Journal of Sport Psychology in Action, 4(3), 181-190. https://doi.org/10.1080/21520704.2013.820247

Prabowo, A., Waluyo, Marsiyem, \& Ihsan, N. (2020). The Relation of Togok Flexibility and Limb Muscle Power to Perform Power Jump Heading on Football Extracurricular of SMK Negeri 2 Muara Enim Students. Proceedings of the 1st Progress in Social Sciences, Humanities and Education Research Symposium (PSSHERS 2019), 464, 960-962. https://doi.org/10.2991/assehr.k.200824.213

Raibowo, S., Adi, S., \& Hariadi, I. (2020). Efektivitas dan Uji Kelayakan Bahan Ajar Tenis Lapangan Berbasis Multimedia Interaktif. Jurnal Pendidikan: Teori, Penelitian Dan Pengembangan, 5(7), 944-952. https://doi.org//10.17977/jptpp.v5i7.13726 
HALAMAN Jendral A. Yani Street Lorong Gotong Royong 9/10 Ulu OLAHRAGA

Raibowo, S., Ilahi, B. R., Prabowo, A., \& Nopiyanto, Y. E. (2021). Penguasaan

Keterampilan Dasar Futsal UKM FORKIP Universitas Bengkulu. Jurnal

Pendidikan Kesehatan Rekreasi, 7(2), 333-341.

https://doi.org/10.5281/zenodo.4897656

Septiyanto, A., \& Suharjana. (2016). Pengaruh Metode Latihan Imagery dan Konsentrasi Terhadap Ketepatan Floating Service Atlet Bola Voli DIY. Jurnal Cakrawala Pendidikan, 35(3), 412-420. https://doi.org/10.21831/cp.v35i3.8249

Sin, T. H., \& Aprinanda, M. (2020). The Impact of Concentration Toward Soccer Player Shooting Ability of Soccer School Batuang Taba Padang City. International Journal of Research in Counseling and Education, 4(1), 35. https://doi.org/10.24036/00245za0002

Tache, N., Lubis, L., \& Saputra, L. (2017). Concentration Level Differences between Athletes of Body Contact and Non-Body Contact Sports. Althea Medical Journal, 4(3), 396-401. https://doi.org/10.15850/amj.v4n3.1188

Tangkudung, J. (2018). SPORT PSYCHOMETRICS: Dasar-Dasar dan Instrumen Psikometri Olahraga (1st ed., Issue October). Raja Grafindo Persada.

Terry, P. C., \& Karageorghis, C. I. (2011). Music in Sport and Exercise. In The New Sport and Exercise Psychology Companion (Issue January 2011, pp. 359-380).

Triananda, A., Syafrial, \& Nopiyanto, Y. E. (2021). Karakteristik Psikologis Atlet PON Bengkulu Ditinjau dari Cabang Olahraga Individu. Sport Gymnastics: Jurnal Ilmiah Pendidikan Jasmani, 2(1), 126-137. https://doi.org/10.33369/gymnastics.v2i1.14862

Widiastuti, I. A. E., Irawati, D., \& Lestrarini, I. A. (2017). Hubungan Nilai Aktivitas Fisik dengan Kadar Trigliserida dan Kolesterol HDL Pada Pegawai Fakultas Kedokteran Universitas mataram. Jurnal Kedokteran Unram, 6(4), $18-21$.

Yusuf, B. S. P., Ugelta, S., \& Imanudin, I. (2017). Tingkat Kecemasan Wasit Sebelum, Selama Dan Sesudah Memimpin Pertandingan Futsal. JTIKOR (Jurnal Terapan Ilmu Keolahragaan), 3(2), 37-40.

Zavecz, Z., Nagy, T., Galkó, A., Nemeth, D., \& Janacsek, K. (2020). The Relationship Between Subjective Sleep Quality and Cognitive Performance in Healthy Young Adults: Evidence from Three Empirical Studies. Journal Scientific Reports, 10(1), 1-12. https://doi.org/10.1038/s41598-020-61627-6 